\title{
Clinical and laboratory manifestations of childhood and adult-onset systemic lupus erythematosus in Cipto Mangunkusumo Hospital
}

\author{
Syarif Faisal, MD; Arwin Akib, MD; Taralan Tambunan, MD
}

\begin{abstract}
Background Childhood-onset SLE is more severe than the adult type. Objective To compare the clinical and laboratory manifestations of childhood- and adult-onset systemic lupus erythematosus (SLE). Methods A retrospective study on child and adult SLE patients was conducted in the Division of Pediatric Allergy and Immunology, Department of Child Health and Department of Internal Medicine, Medical School, University of Indonesia/CiptoMangunkusumo Hospital (FKUI/RSCM) Jakarta.

Subjects One hundred and twenty-nine subjects met the study criteria consisting on 54 childhood- onset (41.9\%), 75 adult-onset (58.1\%), and $122(94.6 \%)$ females and 7 (5.4\%) males from January 1995 until December 2000.

Results Fever, arthralgia and vasculitis were the most frequent signs found in both childhood-onset and adult-onset SLE. The liver, spleen, lymph nodes, cardiovascular, gastrointestinal tract, and eyes were the organs involved and significantly had a larger proportion in the childhood-onset. Decrease of C3 was more frequently found in the childhood-onset. Out of 17 childhood-onset patients who died, 13 died at the age of 0-11 year-old. Two of the adultonset patients also died.

Conclusion Childhood-onset SLE had some different characteristics compared to adult form [Paediatr Indones 2003;43:199204].
\end{abstract}

Keywords: systemic lupus erythematosus (SLE), childhood-onset, adult-onset, American College of Rheumatism (ACR).

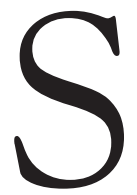
ystemic lupus erythematosus (SLE) is a multisystem inflammatory disorder characterized by extensive inflammation of connective tissues and blood vessels. The clinical manifestations vary widely and the course of disease is unpredictable. ${ }^{1-3}$ Clinical manifestation of childhood SLE is almost similar to adult type, although the involvement of reticuloendothelial system in children is more prominent. ${ }^{4-5}$ Untreated SLE often becomes progressive and can lead to death. ${ }^{1-3}$ Ten to twenty percent of cases are initially diagnosed in the childhood period. ${ }^{6}$ Childhood SLE is usually more severe than the adult type. ${ }^{7}$ About $66-75 \%$ of children with SLE develop nephritis. ${ }^{2}$ There is no definite cutoff point of the age of childhood-onset. The frequently used cutoff point of age is 14-16 year-old for the time of onset or the time of diagnosis. Several studies used lower or higher cutoff point. ${ }^{6}$

The etiology of the disease is multifactorial, although the exact etiology is not known yet. Factors that had been suspected are immunological abnormality that affects nuclear or cytoplasmic antigen, chronic viral infection, hormonal factors, immunogenetic predisposition and environmental trigger factors such as photosensitivity and drug reaction. $1,8-10$ The disease starts with the inability of the body immune system to recognize self-antigen structure that leads to anautoimmune mechanism. The autoantibody will bind to an autoantigen and forms an immune complex that precipitates in the tissues. The

From the Department of Child Health, Medical School, University of Indonesia, Cipto Mangunkusumo Hospital, Jakarta.

Request reprints to: Arwin Akib, MD, Division of Pediatric Allergy and Immunology, Department of Child Health, Medical School, University of Indonesia, Jakarta, Indonesia.Tel. 62-21-3144757, Fax. 62-21-3907743. 
immune complex may be formed locally at the site of the antigen such as the basal membrane (the layer of capillary vessels and glomeruli). This leads to the activation of complement so that inflammation reaction occurs and lesion develops at the site. ${ }^{11}$ The diagnosis of SLE is established when there are at least four of the American College Rheumatism (ACR) criteria. ${ }^{12}$ One of the therapeutic goal of SLE is to suppress the inflammatory process and the formation of the immune complex. ${ }^{13}$ Factors that affect the prognosis are age at the time of diagnosis, time lapse between onset and time of diagnosis, disease manifestations, disease activity, demography such as race, sex, age of onset, socioeconomic status, community health care system, environment, and geography. 1,2,14,15

This study aimed to compare the clinical and laboratory manifestations of childhood- and adultonset SLE.

\section{Methods}

This was a descriptive study conducted retrospectively by studying secondary data from medical records of childhood and adult-onset SLE patients at the Division of Pediatric Allergy and Immunology, Department of Child Health and the Department of Internal Medicine, FKUI/RSCM from January 1995 to December 2000. The diagnosis of SLE was established based on the revised ACR criteria 1997. The collected data were divided into three age groups: 0-11 year-old, 12-18 year-old, and >18 year-old. Data of age of onset, age at the time of diagnosis, sex, clinical and laboratory manifestations, biopsy result, and cause of death were recorded. To examine the proportion of data ineligible for chi square test, we used the log likelihood test. Inclusion criteria were SLE patients who were inpatients or outpatients of the Outpatient Clinic of Pediatric Allergy Immunology, Department of Child Health and the Department of Internal Medicine, FKUI/RSCM from January 1995 until December 2000 and met the four criteria of the revised ACR criteria 1997. Exclusion criterion was incomplete data of the medical record.

\section{Results}

During the period of six years (January 1995 until December 2000), there were 139 SLE patients, but only 129 patients were included in the study. Twentytwo patients came from the Department of Child Health and 107 patients from the Department of Internal Medicine.

One hundred and twenty two (94.6\%) patients were female and seven (5.4\%) patients were male; the $0-11$ year-old group consisted of 12 girls and 5 boys; the 12-18 year-old group consisted of 37 girls. In the adult group, there were 73 women (97\%) and 2 men. There was no significant difference among them $(p=0.129)$.

Seventy-five patients (58\%) had adult-onset, whereas childhood-onset was found in 17 patients $(13 \%)$ at $0-11$ years old and 37 patients (29\%) at 12 -

Table 1. Clinical manifestations based on age of onset

\begin{tabular}{|c|c|c|c|c|}
\hline & $\begin{array}{l}0-11 \text { year-old } \\
(n=17) \\
n\end{array}$ & $\begin{array}{l}\text { 12-18 year-old } \\
(n=37) \\
n\end{array}$ & $\begin{array}{l}\text { Adult-onset } \\
(\mathrm{n}=75) \\
\mathrm{n}\end{array}$ & p \\
\hline Fever** & 16 & 32 & 69 & 0.556 \\
\hline Arthralgia & 11 & 33 & 66 & $0.036^{*}$ \\
\hline Vasculitis & 15 & 27 & 44 & $0.041^{*}$ \\
\hline Hair loss & 2 & 24 & 44 & $0.001^{*}$ \\
\hline Fatigue & 9 & 22 & 47 & 0.752 \\
\hline Stomatitis & 4 & 17 & 37 & 0.153 \\
\hline Lymphadenopathy & 2 & 16 & 16 & $0.016^{*}$ \\
\hline Weight loss & 5 & 13 & 12 & 0.064 \\
\hline Visual disturbance & 1 & 9 & 10 & 0.160 \\
\hline Seizure ${ }^{\star *}$ & 0 & 6 & 3 & $0.026^{*}$ \\
\hline Diarrhea** & 0 & 8 & 7 & $0.023^{*}$ \\
\hline Gangrene** $^{\star *}$ & 0 & 0 & 1 & 0.100 \\
\hline Raynaud syndrome & - & - & - & NA \\
\hline
\end{tabular}


18 years old. In 91 patients (71\%), the diagnoses were established at 18 years old or older, thirteen patients $(10 \%)$ at $0-11$ years old, and 25 patients $(19 \%)$ at 12-18 years old.

Besides vasculitis $(\mathrm{p}=0.041)$, other clinical manifestations that were significantly different were arthralgia $(p=0.036)$, hair loss $(p=0.001)$, lymphadenopathy $(p=0.016)$, seizures $(p=0.026)$, and diarrhea $(\mathrm{p}=0.023)$ (Table 1).

The involvement of liver, spleen, and lymph nodes $(p=0.001)$, cardiovascular $(p=0.005)$, gastrointestinal $(p=0.001)$, and eye $(p=0.014)$ were significantly different between the childhood and the adult-onset groups and occurred more frequently in the childhood-onset group (0-11 year-old) except for the eye because it was not found among the childhood-onset SLE patients (0-11 year-old) (Table 2$)$.

Not all patients in both onset groups had undergone laboratory examination (See Table 3$)$. Leukopenia $(p=0.021)$ and increased ESR $(p=0.034)$ were significantly different statistically using the chi-square test. The proportion of leukopenia was higher in the 12-18 year-old group and increased ESR was more frequently found in the 0-11 year-old group.

The proportions of proteinuria $(\mathrm{p}=0.186)$ and hematuria $\mathrm{p}=0.265$ ) between the childhood-and the adult-onset group were not significantly different, and so was the serological examination between the two groups.

There was a significant difference of $\mathrm{C}_{3}$ complement $(p=0.009)$ between the childhood-onset and the adult-onset group. There were more subjects of the $0-11$ year-old ( 11 out of 15 ) and the $12-18$ yearold group (20 out of 28) that had decreased $\mathrm{C}_{3}$ compared to the adult- onset group (26 out of 64). Biopsy was conducted only on six childhood-onset patients and five adult-onset patients. Our study found that 19 patients died, 17 of which were the childhood-onset patients (13 from the $0-11$ year-old group and four from the 12-18 year-old group). Two of the adult-on-

Table 2. Organs involvement based on age of onset

\begin{tabular}{lllll}
\hline & $\begin{array}{l}\mathbf{0 - 1 1} \text { year-old } \\
\mathbf{( n = 1 7 )}\end{array}$ & $\begin{array}{l}\mathbf{1 2 - 1 8} \text { year-old } \\
\mathbf{n}=\mathbf{3 7}) \\
\mathbf{n}\end{array}$ & $\begin{array}{l}\text { Adult-onset } \\
\mathbf{n}=\mathbf{n})\end{array}$ & $\mathbf{p}$ \\
$\mathbf{n}$ & \\
\hline Skin and mucous & 17 & 35 & 70 & 0.689 \\
Renal (lupus nephritis) & 13 & 31 & 66 & 0.459 \\
Joint, bone, muscle & 11 & 27 & 46 & 0.477 \\
Liver, spleen, lymph nodes & 11 & 17 & 13 & $0.001^{*}$ \\
Cardiovascular & 9 & 10 & 12 & $0.005^{*}$ \\
Lung & 6 & 4 & 8 & 0.092 \\
Gastrointestinal tract & 7 & 10 & 6 & $0.001^{*}$ \\
CNS & 2 & 8 & 5 & 0.067 \\
Eye & 0 & 5 & 1 & $0.014^{* *}$ \\
\hline${ }^{*}=$ significantly different & & ${ }^{* *}=\log$ likelihood test
\end{tabular}

TABle 3. Laboratory Findings based on AGE OF ONSET

\begin{tabular}{|c|c|c|c|c|}
\hline & $\begin{array}{l}0-11 \text { year-old } \\
(n=17) \\
n\end{array}$ & $\begin{array}{l}12-18 \text { year-old } \\
(n=37) \\
n\end{array}$ & $\begin{array}{l}\text { Adult-onset } \\
(n=75) \\
n\end{array}$ & $p$ \\
\hline Anemia & 13 & 26 & 45 & 0.323 \\
\hline Coomb's test $(+)^{\star \star}$ & $3(n=7)$ & $14(n=25)$ & $27(n=45)$ & 0.642 \\
\hline Leukopenia & 3 & 17 & 17 & $0.021^{*}$ \\
\hline Thrombocytopenia & 2 & 9 & 8 & 0.148 \\
\hline Increased ESR & 16 & 24 & 46 & $0.034^{*}$ \\
\hline Proteinuria & $15(n=17)$ & $29(n=37)$ & $66(n=75)$ & 0.186 \\
\hline Hematuria & $8(n=12)$ & $25(n=26)$ & $52(n=55)$ & 0.265 \\
\hline ANA $(+)$ & $14(n=15)$ & $26(n=29)$ & $34(n=42)$ & 0.223 \\
\hline Anti dsDNA (+) & $14(n=15)$ & $25(n=31)$ & $47(n=55)$ & 1.000 \\
\hline LE cell (+) & $1(n=8)$ & $3(n=8)$ & $2(n=8)$ & 1.000 \\
\hline Decreased $\mathrm{C}_{3}$ & $11(n=15)$ & $20(n=28)$ & $26(n=64)$ & $0.009^{*}$ \\
\hline Decreased $\mathrm{C}_{4}$ & $11(n=16)$ & $14(n=26)$ & $25(n=59)$ & 0.091 \\
\hline
\end{tabular}


set patients died from chronic renal failure. Among the 17 died patients in childhood-onset group, the causes of death were gastrointestinal bleeding (4 patients), cerebral SLE/encephalopathy (2 patients), metabolic acidosis (2 patients), CRF or terminal CRF (2 patients), aspiration (1 patient), and heart failure (1 patient)

\section{Discussion}

Out of the 129 SLE patients who met the criteria of inclusion, 54 were childhood-onset, 32 of them were from the Department of Internal Medicine. The ratio between female and male patient was 2 3:1 among the childhood-onset, increased up to 13:1 among the adult-onset. This increase is due to menarche and it will decrease during the menopause period. ${ }^{16}$ The mean of age at diagnosis was 15.8 year-old (SD 3.81). In the childhood-onset group, the age range was 6-18 year-old, mean age was 13.7 year-old, most were in the $12-18$ year-old group. No patient younger than 5 year-old was found. Fever, arthralgia, and vasculitis were the most frequently found clinical manifestations, both in the childhood-onset group and the adult-onset group. Because of that, patients who have those signs need to be evaluated further to establish the diagnosis of SLE. The occurence of vasculitis was significantly different between the groups, and most frequently found in the 0-11 year-old group. Arthralgia, hair loss, lymphadenopathy, seizure and diarrhea were most frequently found in the 12-18 year-old group.

Our study found that seizure was the sign of CNS involvement (18.5\%), whereas personality disturbance, mental state change, psychosis, chorea, and intracranial bleeding were not found. These findings were almost similar with a study in Singapore. ${ }^{17}$ Neuropsychiatric manifestation of SLE is frequently found in many forms with various pathogenesis. Vasculopathy factor and other mechanisms can also lead to bleeding due to arterial hypertension or thrombocytopenia, corticosteroid effect, and complication of sepsis. ${ }^{3}$

SLE patients often suffer from anemia due to various causes. It might be due to general causes such as chronic disease, blood loss, nutritional deficiency, malabsorption, or bone marrow suppression. Our study found 17 out of 54 (31\%) childhood-onset patients had hemolytic anemia. That finding was lower than that of the study done by Szer ${ }^{5}$ that found $44 \%$. The anemia might also be caused by the disease itself, such as hemolytic process of the erythrocyte that could be proven by positive Coomb's test. ${ }^{18}$ The proportion of patients suffering from leukopenia and increased ESR showed a significant difference among the groups. The 12-18 year-old group suffered from leukopenia more and the 0-11 yearold group suffered from increased ESR more. Leukopenia was related to the disease activity and the presence of autoantibody to lymphocyte. The presence of leukopenia was an important sign of acute SLE. The low number of leukocyte leads the SLE patients susceptible to infection. ${ }^{19,} 20$

Forty-four out of 54 (81\%) childhood-onset patients had proteinuria. This result was higher than that of other studies which revealed only $69 \%,{ }^{5} 60 \%,{ }^{9}$ and $65 \% .{ }^{21}$ Proteinuria and hematuria are signs of renal involvement. Proteinuria might be caused by renal vein thrombosis which is unresponsive to steroid and cytotoxic treatment, so that physicians should differentiate it from proteinuria due to worsening of renal impairment. ${ }^{18,22}$ Our study found $91 \%$ of childhood-onset patient had positive ANA. Iqbal ${ }^{11}$, from his study found 97\% of childhood-onset patients with positive ANA. Examination of ANA is sensitive but not specific because it can also be found in other diseases such as dermatomyositis, Sjogren syndrome, scleroderma, and rheumatoid arthritis. ${ }^{2,4}$ Seropositivity for ANA is found in almost $5 \%$ of population, although only few patients continue to develop SLE. ${ }^{11}$ Anti ds-DNA was found in 39 out of $46(85 \%)$ childhood-onset patients. This result was similar with other study in various country (80-90\%). ${ }^{23}$ Some researchers reported that examination of anti ds-DNA gave different results. The difference needs to be evaluated further because anti ds-DNA examination is specific for diagnosis of SLE. Increased titer might also be used as a parameter of SLE activity.

Our study found that 31 out of 44 childhoodonset patients suffered from active lupus nephritis. Decreased complement level will occur in children with active nephritis and will be back to nor- 
Syarif Faisal et al: Clinical and laboratory manifestations of childhood and adult-onset SLE

mal in the remission period. ${ }^{2}$ Level of serum complement could be used as a prognostic and diagnostic indicator of SLE patients. ${ }^{17,} 24$ Our study found that the level of $\mathrm{C}_{3}$ complement differed significantly between the two onset groups in which the 12-18 year-old group was predominantly affected.

Renal biopsies were only performed on 6 out of 44 patients of childhood-onset group who suffered from renal involvement. Course of the disease and prognosis of lupus nephritis were related to the pathological lesion of the kidney. Proliferative diffuse glomerulonephritis has the worst prognosis. ${ }^{19}$

We concluded that childhood-onset SLE has some different characteristics from the adult-form.

\section{References}

1. Cassidy JT, Petty RE. Systemic lupus erythematosus. In: Cassidy JT, Petty RE, editors. Textbook of pediatric rheumatology. $2^{\text {nd }}$ ed. New York: Churchill Livingstone; 1990. p. 261-328.

2. Cassidy JT. Clinical assessment of immune-complex disease in children with systemic lupus erythematosus. J Pediatr 1976;89:523-6.

3. Akib AAP. Lupus eritematosus sistemik. In: Akib AAP, Matondang CS, editors. Buku ajar alergiimunologi anak. Jakarta: IDAI; 1996. p. 245-69.

4. Lehman TJA, Hanson V, Singsen BH, Kornreich HK, Bernstein B, King K. The role of antibodies directed against double-stranded DNA in the manifestation of systemic lupus erythematosus in children. J Pediatr 1980;96:657-61.

5. Szer IS, Jacobs JC. Systemic lupus erythematosus in children. In: Lahita RG, editor. Systemic lupus erythematosus. 2nd ed. New York: Churchill Livingstone; 1992. p. 397-411.

6. Font J, Cervera R, Espinosa G, Pallres L, Cassals MR, Jimenez S, et al. Systemic lupus erythematosus (SLE) in childhood: analysis of clinical and immunological findings in 34 patient and comparison with SLE characteristic in adults. Ann Rheum Dis 1998;57:456-9.

7. Celermejer DS, Thoner PS, Baumal R, Arbus GS. Sex differences in childhood lupus nephritis. Am J Dis Child 1984;138:586-8.
8. Hopkinson ND, Muir KR, Oliver MA, Doherty M, Powell RJ. Distribution of cases of systemic lupus erythematosus at time of first symptom in an urban area. Ann Rheum Dis 1995;54:891-5.

9. King KK, Kornreich HK, Bernstein BH, Singsen BH, Hanson $\mathrm{V}$. The clinical spectrum of systemic lupus erythematosus in childhood. Am J Dis Child 1989;13:287-94.

10. Manners PJ. Systemic lupus erythematosus in children. In: Matondang CS, Akib AAP, editors. Strategi pendekatan klinis berbagai penyakit alergi dan reumatik pada anak. Proceedings of the $36^{\text {th }}$ Pediatric Continuing Medical Education, Medical School, University of Indonesia; 1995 Nov 10-11; Jakarta, Indonesia. Jakarta: Bina Rupa Aksara; 1995.

11. Igbal S, Sher MR, Good RA, Cawkwell GD. Diversity in presenting manifestation of systemic lupus erythematosus in children. J Pediatr 1999;135:500-5.

12. Petri MA. Systemic lupus erythematosus: clinical aspects. In: Koopman WJ, editor. Arthritis and allied conditions. 14th ed. Philadelphia: Lippincott; 2000. p. $1455-79$.

13. Behrman RE. Rheumatic diseases of childhood, inflammatory diseases of connective tissue, collagen diseases. In: Kliegman RM, Nelson WE, editors. Nelson textbook of pediatrics. 14th ed. Philadelphia: WB Saunders; 1992. p. 610-27.

14. Gladman DD, Urowitz MB. Prognostic subsets and mortality in systemic lupus erythematosus. In: Wallace DJ, Hahn BH, editors. Dubois' lupus erythematosus. 5th ed. Baltimore: Williams and Wilkins; 1997. p. 1213-27.

15. Woolf A, Croker B, Osofsky SG. Nephritis in children and young adults with systemic lupus erythematosus and normal urinary sediment. Clin Pediatr 1979;5:678-85.

16. Reeves WH, Lahita RG. Clinical presentation of systemic lupus erythematosus in the adult. In: Lahita RG, editor. Systemic lupus erythematosus. $2^{\text {nd }}$ ed. New York: Churchill Livingstone; 1992. p. 369-96.

17. Feng PH, Boey ML. Systemic lupus erythematosus in Chinese: the Singapore experience. Rheumatol Int 1982;2:151-4.

18. Hochberg MC. Epidemiology of systemic lupus erythematosus. In: Lahita RG, editor. Systemic lupus erythematosus. 2nd ed. New York: Churchill Livingstone; 1992. p. 103-17. 


\section{Paediatrica Indonesiana}

19. Teodorescu M, Froelich CJ. Laboratory evaluation of systemic lupus erythematosus. In: Lahita RG, editor. 2nd ed. NewYork: Churchill and Livingstone; 1992. p. 3456-8.

20. Horckberg MC, Boyd RE, Aherm JM. Systemic lupus erythematosus: a review of clinico-laboratory features and immunogenic markers in 150 patients with emphasis on demographic subsets. Pediatr Infect Dis 1988;7:523-6.

21. Caeiro F, Michielson FMC, Bernstein R, Hughes GRV, Barbara MA. Systemic lupus erythematosus in childhood. Ann Rheum Dis 1981;40:325-31.
22. Lehman TJA. Systemic lupus erythematosus in childhood and adolescence. In: Wallace DJ, Hahn BH, editors. Dubois' lupus erythematosus. 5th ed. Baltimore: Williams and Wilkins; 1997. p. 851-70.

23. Caeiro F, Michielson FMC, Bernstein R, Hughes GRV, Ansell BM. Systemic lupus erythematosus in childhood. Ann Rheum Dis 1981;40:325-31.

24. Ting CK, Hsieh KH. A long term immunological study of childhood-onset systemic lupus erythematosus. Ann Rheum Dis 1992;51:45-51. 